\title{
Konsortium af europæiske forskningsbiblioteker: Planer om et internationalt projekt
}

Af J. Michael Smethurst, Director General ved British Library.

De sidste to årtiers hurtige udvikling indenfor registreringen af den europæiske trykte arv er velkendt af alle bibliotekarer og næsten af enhver bruger af bibliotekerne. Mange biblioteker er gået fra individuelle kortkataloger til maskinelt læsbare systemer, man har diskuteret standarder i behørige fora, formater er blevet etableret og fælles problemer er blevet debatteret. På dette trin i udviklingen er faren for forskellige systemers uforenelighed og dobbeltarbejde blevet åbenlys, og en uafhængig vurdering i international sammenhæng synes påkrævet.

Disse overvejelser har ført til, at lederne for hhv Bayerische Staatsbibliothek og British Library (London afd.) har taget initiativ til at indkalde til to møder, som BayerischeStaatsbibliothek i München var vært for. Repræsentanter fra alle større europæiske forskningsbiblioteker var inviteret for at sammenligne udviklingen indenfor retroinddateringen i de respektive institutioner og lande, samt udforske mulighederne for at dele ressourcer med henblik på en registrering af hele Europas bogbestand, og gøre denne tilgængelig i ét maskinelt læsbart system. Diskussionerne koncentrerede sig om håndsatsperioden (ca. 1450-1830).

Den første konference, der fandt sted fra den 18. til den 30. november 1990, resulterede $i$ dannelsen af en international arbejdsgruppe med Dr Ann Matheson, National Library of Scotland, som formand. Denne arbejdsgruppe havde som opgave at 'udarbejde en europæisk plan vedr. samarbejde mellem større europæiske biblioteker med videnskabelige og nationale samlinger, der skal sikre fælles anvendelighed via databaser til minimal pris på non-profitable vilkår . Arbejdsgruppen rapporterede tilbage i slutningen af 1991 og anbefalede oprettelsen af en enkelt data-enhed i Europa, som til en start skal indeholde en database med en registrering af den europæiske trykte arv ca. 1450-1830, baseret på RLIN systemet. Ar- 
bejdsgruppen anslog, at det samlede antal poster ville nå op på 4,5 mill. Poster dækkende perioden 1830-1950 skulle udgøre et separat projekt, som måske ville gøre brug af metoder fra retrokonverteringsprojekter.

På den anden München-konference, der blev afholdt i dagene 29. - 30. januar 1992, godkendtes arbejdsgruppens anbefalinger, og det blev besluttet at danne et midlertidigt konsortium, der havde som formål at iværksætte et studium af mulighederne i disse anbefalinger. Udgifterne til dette forstudium blev anslået til $£ 50.000$, som skulle dækkes af konsortiets medlemmer. Ved slutningen af München konferencen og i de efterfølgende uger udtrykte 18 biblioteker ønske om at deltage i konsortiet. Disse er: National Library of Wales, Aberystwyth; Bibliothèque Royale de Belgique, Bruxelles; Det kongelige Bibliotek, København; National Library of Ireland, Dublin; Trinity College, Dublin; National Library of Scotland, Edinburgh; Biblioteca Nazionale Centrale, Firenze; University Library, Glasgow; NiedersächischeStaats- und Universitätsbibliothek, Göttingen; Koninklijke Bibliotheek, s-Gravenhage; University Library, Helsinki; National and University Library, Ljubljana; British Library, London; University Library, London; Bayerische Staatsbibliothek, München; Bodleian Library, Oxford; Bibliothèque Nationale, Paris; Istituto Centrale per il Catalogo Unico delle Biblioteche Italiane (ICCU), Rom; Biblioteca Nazionale Centrale, Rom; Kungliga Biblioteket, Stockholm.

De, der således havde meldt sig som stiftende medlemmer, blev inviteret til at sende en repræsentant til et møde den 22. april 1992, der blev afholdt $\mathrm{i}$ Bibliothèque Nationale i Paris. På dette møde blev kravene til databasen yderligere defineret:

1. Den skal kunne bruges som referenceværk for forskning

2. Den skal kunne bruges til at downloade poster ved katalogisering

3. Posterne skal indføres i UNIMARC format

4. Posterne skal opstilles hierarkisk, begyndende med $\operatorname{ISBD}(\mathrm{A})$ specifikationen

5. Den skal kunne indeholde poster fra alle retrospektive katalogiseringer

6. Databasen skal bruge nationale standarder i forbindelse med navneformskontrol

7. Konsortiet skal fungere som kontrolinstans vedrørende redigeringsprocedurer, tilføjelser og slettelser

8. Databasen skal inkorporere standarder vedr. lokalisering for at fungere som union katalog

9. Der skal være felter til anmærkninger vedr. specifikke eksemplarer

10.Databasen skal være let tilgængelig over hele Europa via telekommunikation eller andre distributionssystemer, on-line så vel som off-line 
Mødet valgte en lille bestyrelse, som fik til opgave at sørge for planens tekniske og organisatoriske aspekter, udpege en eller flere konsulenter til at udvikle disse, samt aflægge rapport i slutningen af 1992. Formanden er J.M. Smethurst, London, kassereren E. Mittler, Göttingen, og medlemmerne er N.I. Boserup, København, F. Dupuigrenet Desroussilles, Paris, Claudia Fabian, München, og A. Matheson, Edinburgh. L. Hellinga fra British Library i London vil fungere som sekretær.

Skønt fremgangsmåder og anbefalinger fra møderne er blevet rapporteret til IFLAs faglige råd (og godkendt af dette) og til EC, er alle initiativer indtil nu blevet taget uden at søge nogen form for støtte. Ved at garantere relativt små beløb og deres velvilje forventer medlemmerne af det midlertidige konsortium at kunne gøre hurtige fremskridt. Det er indlysende, at jo større antallet af deltagende institutioner er, jo mindre vil udgifterne for den enkelte deltager være, og jo større er mulighederne for at få råd til moderne teknologi. Men betydningen af den bredest mulige deltagelse er større end de umiddelbare finansielle hensyn: det bredest mulige spektrum af bibliografiske interesser i projektets tidlige fase vil sikre, at de mange facetter indenfor bibliografiske traditioner vil blive taget i betragtning; dette vil således fremme en fleksibel anvendelse for ethvert system og i sidste ende gøre projektet til en succes. Det er med dette som mål at vi ønsker at gøre alle biblioteker og institutioner med samlinger af trykt materiale fra håndsatsperioden opmærksomme på dette initiativ.

Ansøgninger om medlemsskab er velkomne. Skriv venligst i første omgang til Dr Lotte Hellinga, British Library, Great Russell Street, London WC1B 3DG. Fax: 0713237736.

Oversættelse: Kristian Gandrup

\section{Litteratur:}

J.M. Smethurst, F.G. Kaltwasser (eds.): Retrospective Cataloguing in Europe: 15th19th Century Printed Materials. München (etc), K.G. Saur, 1992.

Claudia Fabian: Die Gründung der 'Eurodatenbank' für Altbestandskatalogisierung in Europa' in Zeitschrift für Bibliothekswesen und Bibliographie 39, 1992, pp. 207-16.

\section{Rapporter:}

European Working Group on Retrospective Cataloguing: Final Report. [Forelagt for München Konferencen, januar 1992].

Henry Snyder and Heidi L. Hutchinson, with the assistance of Laura A. Stalker: $A$ Comparative and Analytical Study of Cataloguing Rules employed in Europe for the Cataloguing of the Hand Press. [Rapport lavet til arbejdsgruppen, endelig version under udarbejdelse]. 